\title{
Monetary Policy Mechanisms and Economic Growth Stability in Nigeria
}

\author{
Cordelia Onyinyechi Omodero ${ }^{1} \&$ M. C. Okafor ${ }^{2}$ \\ ${ }^{1}$ Department of Accounting, College of Management and Social Sciences, Covenant University, Ota, Nigeria \\ ${ }^{2}$ Department of Accounting, College of Management Sciences, Micheal Okpara University of Agriculture, Umudike, \\ Umuahia, Nigeria
}

Correspondence: Cordelia Onyinyechi Omodero, Department of Accounting, College of Management and Social Sciences, Covenant University, Ota, Ogun State, Nigeria.

Received: March 29, 2020

Accepted: May 2, 2020

Online Published: December 10, 2020

doi:10.5430/rwe.v11n6p225

URL: https://doi.org/10.5430/rwe.v11n6p225

\begin{abstract}
The study considers the effectiveness of monetary policy tools in guaranteeing economic growth stability in Nigeria. In recent times monetary policy tools have become very productive in stabilizing an economy. Thus, this study employs three monetary policy instruments which include: money supply, interest rate and exchange rate to examine the effectiveness of the monetary policy on economic growth stability in Nigeria from 1998 to 2018. The findings reveal that the money supply is substantially positive in influencing the GDP, which is used as a proxy for economic growth stability. However, interest rate and exchange rate do not have a significant impact on the GDP. The study concludes that money supply is the most productive monetary policy tool in Nigeria and recommends its proper usage to achieve maximum economic benefit. The relevant financial power (CBN) in the country is encouraged to allow more accessibility to credits by reducing interest rate and exchange rate fluctuations.
\end{abstract}

Keywords: monetary policy, money supply, interest rate, exchange rate, G.D.P., CBN

JEL Classification codes: E42, E43, E51, E52, E58, F31

\section{Introduction}

Economic stability is the concern of every government struggling to achieve developmental objectives in their country. As a result, administrations make relentless effort to exploit all relevant monetary policy tools which are considered suitable for industrialization and growth in their nations. In recent times, economic volatility and loss of equilibrium in an economy have been attributed to the weak monetary policy of a country, hence the emphasis on the efficacy of monetary policy instruments. According to Brima and Brima (2017), monetary policy is one of the fundamental economic policies the government applies to improve financial performance and swiftly amend frequent shocks in an economy. Duskobilov (2017) posits it that monetary policy tools have turned out to be the necessary instruments suitable for economic regulation in virtually all modern economies, thereby incapacitating fiscal policy tools. The primary objectives of monetary policy include price stability, preservation of a balance of payment equilibrium, joblessness reduction and product advancement and sustainable economic progress (Adigwe, Echekoba \& Onyeagba, 2015). However, the fact that monetary policy instruments are so indispensable in financial growth stability does not suggest that fiscal policy tools are irrelevant. Still, the economic realities faced by nations in the present times, have made monetary policy devices more predominant in almost all modern economies.

Monetary policy is concomitant with interest rates and credit obtainability (Ahiabor, 2013). Monetary policy is the method by which the financial power of a nation manages the quantity of cash and frequently aiming at the interest rate to stimulate economic growth and stability. The various forms of monetary policy which include adjustment of the amount of money in rotation are normally applied in practice. The exercise of varying the flow of money through the open deals and acquisitions of obligation issued by the government and credit instruments is known as open market operations (OMO). The continuous market dealings by the monetary power alter the amount of money in circulation, and this influences other market variables which include exchange rate and the interest rates (Ahiabor, 2013). Twinoburyo and Odhiambo (2018) concluded in their review of existing international empirical studies that, the nexus between monetary policy and economic growth tends to be weaker in emerging economies with operational flaws and unfledged financial markets that are feebly incorporated into international markets. 
The most recent modifications in the international monetary design unveil that the era of innovative perspective in the monetary policy and fiscal structure has become a reality (Duskobilov, 2017). The notable switch in the global economy from repossession to enlargement has made the role of monetary policy to move to economic growth sustainability by steadily regularizing the orthodox and eccentric strategies (Williams, 2017). Monetary policy signifies the mechanisms of financial administration connecting a mixture of methods premeditated by the Central Bank of a nation to control the accessibility, worth, quantity and value of the currency in the national economy to attain an estimated macroeconomic equilibrium (Imoisi, Olatunji \& Ekpenyong, 2013). Accordingly, a financial strategy is an intentional move by the Apex Bank of a nation to keep the economy at equilibrium by determining the value and amount of money in circulation within a period, and the accessibility of cash and credits for private sector investment.

It has been divulged that monetary policy in Nigeria has been ineffectual for a period owing to economic domination emanating from dense and tenacious administration budget shortfalls. The dearth of data resulting to problematic statistical examination, inefficient disbursements scheme and poor banking practices such that the CBN finds it challenging in controlling enormous sums of money outside the banking structure (Okonkwo, Egbulonu \& Emerenini, 2015). Omotor (2007) has the view that an unswerving control contrivance could be unsuccessful since there could be a severe effect due to political concerns through the Ministry of Finance and generally conveyed to the CBN. However, the formation of the Central Bank of Nigeria by the CBN Act of 1958, made it the foremost monetary authority in Nigeria with the obligation to uphold and preserve financial firmness and a comprehensive economic arrangement in Nigeria. This mandate on CBN has enabled the development of a dynamic currency market where treasury bills, a monetary tool used for open market operations and floating commitment for government, have grown in capacity and worth. It becomes a conspicuous profitable asset for investors and a basis for liquidity synchronization (Ufoeze, Odimgbe, Ezeabalisi \& Alajekwu).

The monetary policy mechanisms presently in use in Nigeria as recognized by CBN (2018) include the money supply, interest rate, moral suasion, open market operation (OMO) and commercial banks reserve requirement, among others. Thus, the significant gap this study is filling in the assessment of the effectiveness of monetary policy tools on economic stability for some time democracy has prevailed since its restoration. All the studies examined in this study did not consider this sensitive time. Therefore, the current study serves as a scorecard where various democratic administration in Nigeria. Since the reinstatement of democracy in the year 1998.

\section{Literature Review}

\subsection{Theoretical Review}

The economic theories underpinning this research are the Keynesian Theory of Money and the Irving Fishers' quantity theory of money. Keynesians hold the view that expansionary monetary policy allows an increase in the number of credits obtainable through banking operations, thereby triggering a decrease in the interest rates. By applying lesser interest rate, collective overheads on investment and interest-sensitive consumption goods generally rise, thereby producing growth in the real GDP. Thus, monetary policy can impact on the real GDP circuitously. Irving Fisher's quantity theory of money postulates that there is an uninterrupted association between monetary policy instruments, basically the money supply, it's the rapidity of transmission and overall price level in the economy.

\subsection{Empirical Review}

Kumar, Acharya and Ho (2020) examined the effect of monetary policy on the profitability of banks in New Zealand. The study adopted panel data of 19 banks which covered 2006 to 2018. The study used econometric tool of Generalized Method of Moments to estimate the data. The findings revealed that the monetary policy instruments used in the study, which include capital adequacy ratio, non-performing loan ratio and cost to income ratio were major factors determining Banks' profitability in New Zealand. Further disclosures showed that the capital adequacy ratio affected profitability positively, while the other variables impacted negatively on banks' profit level.

Omodero (2020) assessed the response of the capital market to monetary policy amendments from 2000 to 2018 . The study considered the vital role of the capital market in boosting economic stability and the influence of variations in the monetary policy instruments on the capital market. Using the ordinary least squares method, the findings revealed that interest rate changes were harmful to the capital market while the exchange rate had an immaterial effect. However, the study further discovered that the money supply significantly and positively affected the performance of the capital market in Nigeria. The Afonso, Alves and Balhote (2019) considered the interactions between monetary policy and the fiscal policy in 28 E.U. Countries using panel data covering a period from 1970 to 
2015. The results of the study indicated that inflation had a significant negative influence on monetary policy. While the government was encountering debt increment, the primary balances reacted positively to it. The study also established that the initiation of a mutual medium of exchange among 19 E.U. Countries out of the 28 resulted in a negative operational effect, on the interaction of the monetary and fiscal policies.

Nguyen, Papyrakis and Bergeijk (2019) employed monthly data and carried out Vector Auto-regressive analysis to determine the influence of monetary policy on the Vietnamese economy. The study got evidence that interest rates adjustments served as an effective monetary policy instrument in price stability. Although the increase in credit tried to induce inflation, the growth in the broad money supply helped to boost industrial production. In another study, Nguyen (2019) evaluated 45 research works covering a period from 2001 to 2014 using a meta-regression analysis (MRA) to assess the output effects of monetary policy on 32 emerging economies. The study discovered a publication bias among the 45 studies but eventually settled that monetary policy rigidity hurt output. The study further indicated that variables associated with commodity prices had a significant negative impact on the economy.

Miftahu (2019) assessed the impact of monetary policy on the economic growth of Nigeria using a secondary form of data that spanned from 1980 to 2017. The study employed the co-integration test and the ordinary least squares (OLS) method for the analysis of data. The findings showed that the money supply had a favourable impact on GDP while other variables such as interest rate and exchange rate negatively affected the GDP. However, the study established a long-run relationship between the monetary policy and economic growth of Nigeria. Osakwe, Ibenta and Ezeabasili (2019) considered the effect of monetary policy on the performance of the manufacturing sector in Nigeria using data that covered a period from 1986 to 2017. The study employed Autoregressive Distribution Lag (ARDL) for the analysis of data and found that monetary policy instruments were significantly affecting the manufacturing sector output in Nigeria in the short run only. Thus, the authors concluded that monetary policy mechanism might not be beneficial to the manufacturing sector where long-run economic policies are necessary.

Ayodeji and Oluwole (2018) assessed the impact of monetary policy on Nigeria's economic growth using the Johansen co-integration test and Vector Error Correction Mechanism (VECM). The study employed data covering a period from 1981 to 2016 while the monetary policy instruments used in the study as independent variables include the money supply, exchange rate, interest rate and liquidity ratio. The economic growth is the dependent variable and is being represented by the GDP. The study found evidence that the money supply and the exchange rate had a negligible positive impact on GDP. In contrast, interest rate and liquidity ratio exerted a significant adverse effect on economic growth. Lawal, Somoye, Babajide and Nwanji (2018) studied the impact of fiscal and monetary policies interaction on stock market performance in Nigeria using monthly data. The study employed statistical tools of ARDL and EGARCH models which revealed the existence of a long-run relationship between stock market performance and the two economic policies (monetary and fiscal) applied in the study.

Rezabek and Doucek (2018) analyzed monetary policy interaction with fiscal policy in the Czech Republic. The study revealed a lack of complementary role between the two policy measures and suggested improvement on the economic policies. The outcome of their research implies that the harmony between the two economic policies would enhance financial growth stability. Ufoeze et al. (2018) investigated the effect of monetary policy on the economic growth of Nigeria for a period covering 1986 to 2016 using the ordinary least squares method and co-integration test. The study found a long-run relationship among the variables and eventually established that monetary policy rate, interest rate and investment had an insubstantial effect on economic growth. On the other hand, money supply exerted a strong positive impact on economic growth. Tule, Ogundele and Apinran (2018) used Vector Error Correction model to examine the effect of monetary policy instruments on economic growth in Nigeria from 2000 to 2016. The study found that consumer price index, real exchange rate, money supply and interest rate significantly affect economic growth.

Brima and Brima (2017) carried out a study on the effects of monetary policy on private sector investment in Sierra Leone from 1980 to 2014 using various modern econometric tools. The study found that money supply and gross domestic savings had a significant positive impact on private sector investment (PSI). Still, P.S.I. was negatively affected by the rest of the other variables used in the study. Duskobilov (2017) tested the effectiveness of monetary policy tools in ensuring economic stability in Uzbekistan from 2005 to 2016. Using Augmented Dickey-Fuller (ADF) and Phillips-Perron (PP) tests, all data became stationary at first difference. Thus, the study employed a Johansen Co-integration test and discovered the existence of a long term relationship between the variables. With the use of Error Correction Model, the result showed that monetary policy tools favourably impacted on economic growth and also aided the regulation of the entire economy of the nation. Rami and Bassam (2017) examined the effectiveness of monetary policy instruments on economic growth in Jordan using a Vector Error Correction Model and quarterly 
data spanning from 2005 to 2015 . The study found the existence of positive long-term and short-term effects of monetary policy instruments on the growth of real GDP. The findings further revealed that the rediscount rate had an inverse relationship with economic growth both in the short and long terms.

Srithilat and Sun (2017) employed the Johansen co-integration and Error Correction Model (ECM) to investigate the monetary policy influence on Lao PDR economic development from 1989 to 2016 . The study revealed that money supply, interest rate and inflation rate were harmful to real GDP per capita in the long term. At the same time, the entire exchange had a favourable influence on RGDP. Akinjare, Babajide, Isibor and Okafor (2016) used ordinary least squares method to examine the impact of monetary policy effects on economic development in Nigeria from 1970 to 2013 . The result of the study revealed that the interest rate and exchange rate positively affected GDP materially, but money supply had a significant negative impact on GDP. However, inflation was inconsequential in influencing the GDP. Adigwe et al. (2015) used ordinary least square method to assess the effect of monetary policy on Nigeria's economic growth for a period spanning from 1980 to 2010. The result of the study indicated that money supply had a significant favourable influence on GDP but an insignificant negative effect on inflation.

Chipota and Makhetha (2014) used Johansen co-integration and ECM to assess the impact of monetary policy on the economic growth of South Africa for the period covering 2000 to 2010. The findings revealed that money supply, repo rate and exchange rate were immaterial in explaining the changes in the economic growth of South Africa. However, inflation exerted a significant influence on the economic development of South Africa. Ahiabor (2013) investigated the effects of monetary policy on inflation in Ghana using annual data covering 1985 to 2009. The dependent variable employed was the inflation rate while using interest rate, exchange rate and money supply as the independent variable. The study found the existence of a long-run positive relationship among money supply, exchange rate and inflation, while there was a negative correlation between the interest rate and inflation.

\section{Materials and Methods}

To test the efficacy of the monetary instruments on economic stability of Nigeria, the research makes use of a secondary form of data covering a period from 1998 to 2018. The independent variables on which the data have been gathered include broad money supply (M2), interest rate, and exchange rate. The dependent variable on which data have been collected include the GDP, which represents economic growth or stability. Gross domestic product data and Money Supply have been sourced from the Central Bank of Nigeria (CBN) Statistical Bulletin, 2018 edition while data for interest rate and exchange rate are collected from the World Bank Economic Indicators. To demonstrate the application of Ordinary Least Squares (OLS) technique, linear regression analyzed will be Gross Domestic Product (GDP), Money Supply (MSP), Interest Rate (INT) and Exchange Rate (XGR).

Thus, the equation can be written as:

$$
\mathrm{GDP}=\mathrm{f}(\mathrm{MSP}, \mathrm{INT}, \mathrm{XGR})
$$

Where:

GDP = Gross Domestic Product (Nominal);

$\mathrm{f}=$ Functions of MSP (Money Supply), INT (Interest Rate) and XGR (Exchange Rate).

For uniformity of data sets, all the data have been expressed in their logarithm form.

Thus, the equation is rewritten in its linear form as:

$$
\log G D P=\beta_{0}+\log \beta_{1} M S P+\log \beta_{2} I N T+\log \beta_{3} X G R+\varepsilon
$$

The following null hypotheses guide this research:

Ho1: Money supply does not have a material influence on the GDP.

Ho2: Interest rate does not significantly affect the GDP.

Ho3: Exchange rate does not have a substantial impact on GDP. 
Table 1. Data sets and their logarithm form

\begin{tabular}{|c|c|c|c|c|c|c|c|c|}
\hline YEAR & GDP & MSP & INT & XGR & LOG & LOG & LOG & LOG \\
\hline & $\begin{array}{l}\mathrm{N}^{\prime} \\
\text { BILLIONS }\end{array}$ & $\begin{array}{l}\mathrm{N}^{\prime} \\
\text { BILLIONS }\end{array}$ & $(\%)$ & $(\%)$ & GDP & MSP & INT & XGR \\
\hline 1998 & $4,588.99$ & 488.15 & 18.18 & 269.2 & 3.661717 & 2.68855 & 1.259594 & 2.430075 \\
\hline 1999 & $5,307.36$ & 628.95 & 20.29 & 68.3 & 3.724879 & 2.798618 & 1.307282 & 1.834421 \\
\hline 2000 & $6,897.48$ & 878.46 & 21.27 & 69.3 & 3.838691 & 2.943721 & 1.327767 & 1.840733 \\
\hline 2001 & $8,134.14$ & $1,269.32$ & 23.44 & 77.2 & 3.910312 & 3.103572 & 1.369958 & 1.887617 \\
\hline 2002 & $11,332.25$ & $1,505.96$ & 24.77 & 77.5 & 4.054316 & 3.177814 & 1.393926 & 1.889302 \\
\hline 2003 & $13,301.56$ & $1,952.92$ & 20.71 & 72.8 & 4.123903 & 3.290685 & 1.31618 & 1.862131 \\
\hline 2004 & $17,321.30$ & $2,131.82$ & 19.18 & 74.6 & 4.23858 & 3.32875 & 1.282849 & 1.872739 \\
\hline 2005 & $22,269.98$ & $2,637.91$ & 17.95 & 85.3 & 4.34772 & 3.42126 & 1.254064 & 1.930949 \\
\hline 2006 & $28,662.47$ & $3,797.91$ & 16.9 & 90.6 & 4.457314 & 3.579545 & 1.227887 & 1.957128 \\
\hline 2007 & $32,995.38$ & $5,127.40$ & 16.94 & 89.7 & 4.518453 & 3.709897 & 1.228913 & 1.952792 \\
\hline 2008 & $39,157.88$ & $8,008.20$ & 15.48 & 99.3 & 4.592819 & 3.903535 & 1.189771 & 1.996949 \\
\hline 2009 & $44,285.56$ & $9,411.11$ & 18.36 & 92 & 4.646262 & 3.973641 & 1.263873 & 1.963788 \\
\hline 2010 & $54,612.26$ & $11,034.94$ & 17.59 & 100 & 4.73729 & 4.04277 & 1.245266 & 2 \\
\hline 2011 & $62,980.40$ & $12,172.49$ & 16.02 & 100.4 & 4.799205 & 4.085379 & 1.204663 & 2.001734 \\
\hline 2012 & $71,713.94$ & $13,893.22$ & 16.79 & 111.6 & 4.855604 & 4.142803 & 1.225051 & 2.047664 \\
\hline 2013 & $80,092.56$ & $15,154.64$ & 16.72 & 119 & 4.903592 & 4.180546 & 1.223236 & 2.075547 \\
\hline 2014 & $89,043.62$ & $16,238.52$ & 16.55 & 127.5 & 4.949603 & 4.210546 & 1.218798 & 2.10551 \\
\hline 2015 & $94,144.96$ & $18,525.22$ & 16.85 & 126.6 & 4.973797 & 4.267763 & 1.2266 & 2.102434 \\
\hline 2016 & $101,489.49$ & $21,624.63$ & 16.87 & 116.2 & 5.006421 & 4.334949 & 1.227115 & 2.065206 \\
\hline 2017 & $113,711.63$ & $22,363.43$ & 16.84 & 105.4 & 5.055805 & 4.349538 & 1.226342 & 2.022841 \\
\hline 2018 & $127,762.55$ & $25,079.72$ & 16.82 & 109.1 & 5.106404 & 4.399323 & 1.225826 & 2.037825 \\
\hline
\end{tabular}

Source of Data: World Bank Economic Indicators and CBN Statistical Bulletin, 2018 Edition

\section{Data Analysis and Interpretation}

4.1 Trend of M.S.P. and GDP

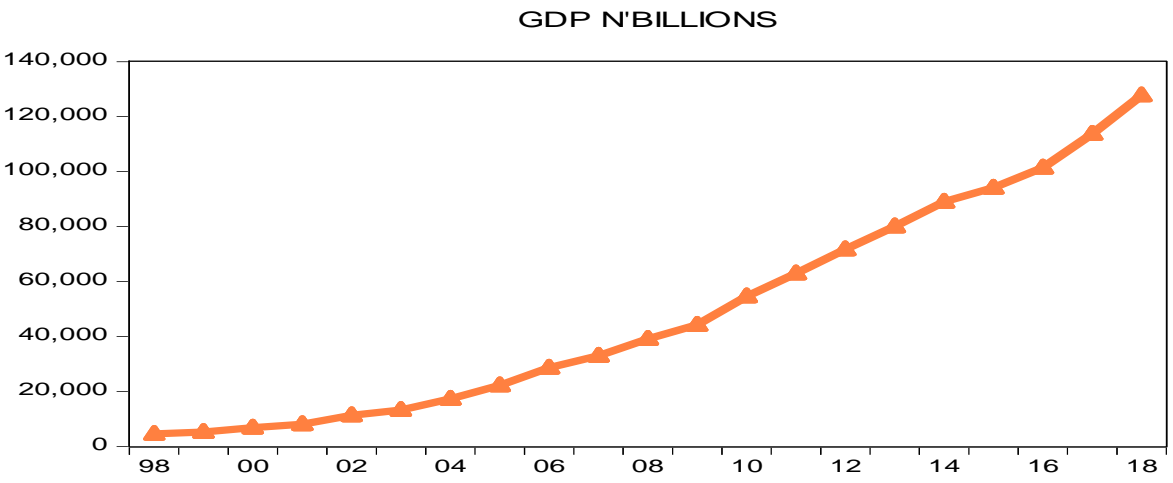

Figure 1. GDP N'BILLIONS

Note: abscissa: Year; ordinate: NGN BILLIONS 
MSP N' BILLIONS

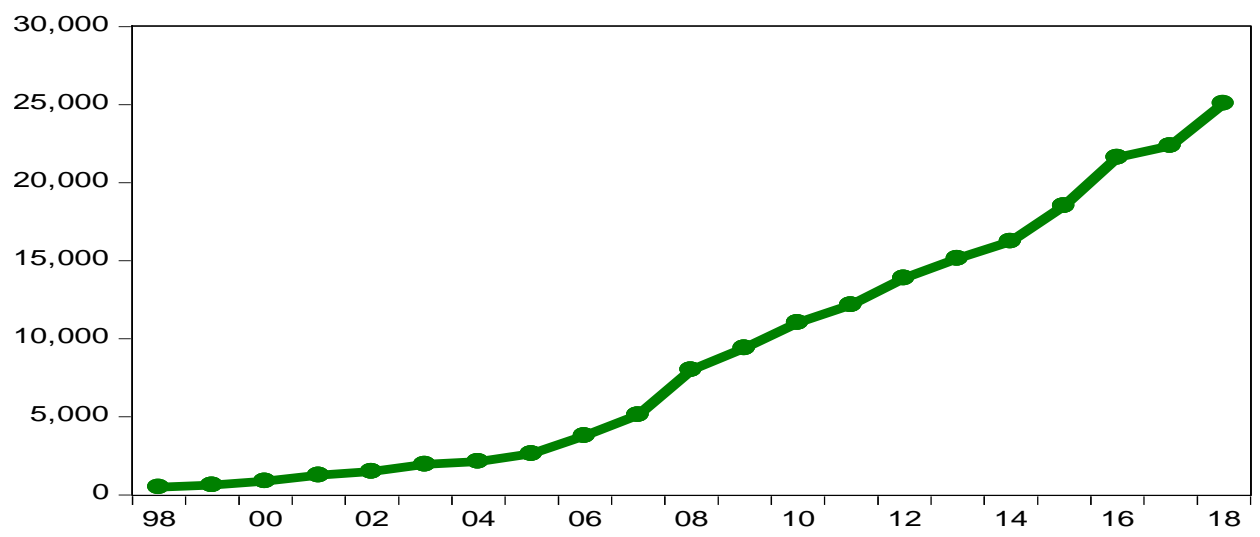

Figure 2. MSP N' BILLIONS

Note: abscissa: Year; ordinate: NGN BILLIONS

Source of Data: CBN Statistical Bulletin, 2018 Edition

The progressive trend of MSP and GDP is a confirmation that the Central Bank of Nigeria has got the green light that proper use of monetary policy tools especially the money supply mechanism serves as the solution to numerous complex economic growth challenges in the country. According to Duskobilov (2017), there is currently a universal awareness that monetary and fiscal policy structures are beginning to take a new dimension to be able to address major economic flaws. This is achieved by governments, through a notable switch to economic growth sustainability which calls for balanced standardization of the conventional and unusual policies (Williams, 2017).

\subsection{Regression Result Interpretation}

Table 2. Model summary

\begin{tabular}{llllll}
\hline Model & $\mathrm{R}$ & R Square & Adjusted R Square & Std. Error of the Estimate & Durbin-Watson \\
\hline 1 & $.996 \mathrm{a}$ & .992 & .990 & .04548405 & 1.024 \\
\hline
\end{tabular}

Note: a. Predictors: (Constant), XGR, MSP, INT; b. Dependent Variable: GDP.

Source: Authors' computation, 2019

Table 2 above shows the summary result of the model used in this study. The R column indicates the correlation value, which are $99.6 \%$ signifying the existence of a healthy and positive relationship between the predictors (MSP, INT \& XGR) and the response variable (GDP). This result points out that monetary policy is a function of economic stability in Nigeria and thus, requires more efficiency in operation. The R Square column provides information concerning the coefficient of determination, and the value is $99.2 \%$. This value means that the monetary policy instruments (MSP, INT \& XGR) employed in this study explain up to $99.2 \%$ of the variation in GDP used as a proxy for economic growth stability. It follows that there is only $8 \%$ the model could not integrate and should be credited to other causes outside the model.

The Durbin-Watson is within the boundary that does not call for concern. The standard error of the regression is employed to check the correctness of the estimates represented by the regression line measuring the accuracy of the projected values. When it is very inconsequential, that is less than 1 or 0 , and it is faultless. Thus, Standard Error of regression has a value of 0.045 . The result suggests that the regression line is error-free. The correlation and the predicted values are also at liberty with inaccuracies. 
Table 3. ANOVA

\begin{tabular}{lllllll}
\hline Model & & Sum of Squares & df & Mean Square & F & Sig \\
\hline 1 & Regression & 4.312 & 3 & 1.437 & 694.785 & .000 \\
\cline { 2 - 7 } & Residual & .035 & 17 & .002 & & \\
\cline { 2 - 6 } & Total & 4.347 & 20 & & & \\
\hline
\end{tabular}

Note: Dependent Variable: G.D.P; b. Predictors: (Constant), X.G.R., M.S.P., INT

Source: Authors' computation, 2019

Table 3 above reveals that the F Statistic is 694.785 while the p-value is $000<0.05$. This result provides evidence that the model is a good fit and statistically material. The result further implies that the monetary policy instruments used in this study collectively influence economic stability in Nigeria positively and significantly.

Table 4. Coefficients

\begin{tabular}{|c|c|c|c|c|c|c|c|c|}
\hline \multirow{2}{*}{\multicolumn{2}{|c|}{ Model }} & \multicolumn{2}{|c|}{ Unstandardized Coefficients } & \multirow{2}{*}{$\begin{array}{l}\text { Standardized Coefficients } \\
\text { Beta }\end{array}$} & \multirow[t]{2}{*}{$\mathrm{T}$} & \multirow[t]{2}{*}{ Sig. } & \multicolumn{2}{|c|}{ Collinearity Statistics } \\
\hline & & $\mathrm{B}$ & Std. Error & & & & Tolerance & V.I.F. \\
\hline \multirow{4}{*}{1} & (Constant) & 1.996 & .566 & & 3.524 & .003 & & \\
\hline & $\overline{\mathrm{MSP}}$ & .811 & .027 & .963 & 30.067 & .000 & .463 & 2.158 \\
\hline & INT & -.387 & .306 & -.045 & -1.267 & .222 & .372 & 2.689 \\
\hline & XGR & -.009 & .091 & -.002 & -.094 & .926 & .729 & 1.371 \\
\hline
\end{tabular}

Note: a. Dependent Variable: G.D.P.

Source: Authors' computation, 2019

The regression result in Table 4 shows that there is no multi-collinearity among the independent variables. The Variance Inflatory Factor (VIF) values of all the variables are far below the benchmark, which is 10 (Gujarati \& Porter, 2009). Table 4 above also provides information regarding the t-statistic and p-value of the individual predictor variables used in this study. The MSP t-statistic is 30.067 with the p-value of $0.000<0.05$ level of significance. This result implies that money supply as a monetary policy instrument has a significant positive impact on economic growth stability. The result of this study is in harmony with the findings of (Ahiabor, 2013; Adigwe et al., 2015; Brima \& Brima, 2017). On the contrast, the result opposes the findings of (Akinjare et al., 2016; Srithilat \& Sun, 2017). Based on the result of this study, interest rate (INT) and exchange rate (XGR) are found immaterial in clarifying the modifications in the economic growth stability. Their p-values are insignificant, that is above $5 \%$ level of significance.

\section{Conclusion and Recommendation}

The study examines the impact of monetary policy instruments on economic growth stability in Nigeria from 1998 to 2018. The result indicates that money supply exerts a significant favourable influence on financial growth stability while interest rate and exchange rate are have insignificant adverse effects and could not be reckoned with at 5\% significance level. Thus, the study concludes that money supply is the most powerful monetary policy instrument in Nigeria, while other tools are yet to be effectual.

Thus, the study recommends that the monetary authority in Nigeria should ensure an adequate supply of money to keep the economy stable. This also should be done with caution as too much money in circulation can cause inflation which is harmful to the economy. On the other hand, the economic growth stability requires effective interest rate and decrease in exchange rate volatility. It is, therefore, expected that the Central Bank of Nigeria (CBN) should work out a monetary system that will guarantee credit accessibility at a reduced interest rate and other associated costs while making an effort to stabilize the rate of exchange in the country. 


\section{Contribution/Originality}

This study contributes substantially to the existing literature in this area of research, but most significantly differs from other studies because it takes cognizance of a sensitive time frame (1998-2018) which marks the restoration period of democracy in the country. Thus, the study assesses the effectiveness of monetary policy instrument in influencing economic stability which is one of the primary objectives of the reinstatement of democracy in Nigeria. The study establishes that money supply is a vital financial policy tool and should be used with caution.

\section{References}

Adigwe, P. K., Echekoba, F. N., \& Onyeagba, J. B. C. (2015). Monetary policy and economic growth, in Nigeria: A critical evaluation. I.O.S.R. Journal of Business and Management, 17(2), 110-119. https://doi.org/10.9790/487X-1722110119

Afonso, A., Alves, J., \& Balhote, R. (2019). Interactions between monetary and fiscal policies. Journal of Applied Economics, 22(1), 131-150. https://doi.org/10.1080/15140326.2019.1583309

Ahiabor, G. (2013). The effects of monetary policy on inflation in Ghana. Developing Country Studies, 3(12), 82-90.

Akinjare, V., Babajide, A. A., Isibor, A. A., \& Okafor, T. (2016). Monetary policy and its Effectiveness on economic development in Nigeria. International Business Management, 10(22), 5336-5340.

Ayodeji, A., \& Oluwole, A. (2018). Impact of monetary policy on economic growth in Nigeria. Open Access Library Journal, 5, e4320, 1-12. https://doi.org/10.4236/oalib.1104320

Brima, S., \& Brima, A. S. (2017). Monetary policy effects on private sector investment: evidence from Sierra Leone. International Journal of Economics and Financial Issues, 7(1), 476-488.

CBN. (2018). Monetary policy instruments used by the CBN. Educational. Retrieved from https://www.cbn.gov.ng/Out/EduSeries/Monetary\%20Policy\%20Instruments\%20used\%20by\%20the\%20CBN. pdf

Chipota, P., \& Makhetha, K. P. (2014). Impact of monetary policy on economic growth: a case study of South Africa. Mediterranean Journal of Social Sciences, 5(15), 76-84. https://doi.org/10.5901/mjss.2014.v5n15p76

Duskobilov, U. (2017). Impact of economic regulation through monetary policy: Impact analysis Monetary policy tools on economic stability in Uzbekistan. International Journal of Innovation and Economic Development, 3(5), 65-69. https://doi.org/10.18775/ijied.i1849-7551-7020.2015.35.2005

Gujarati, D. N., \& Porter, D. C. (2009). Basic Econometrics (5th ed.). Boston: McGraw-Hill Irwin.

Imoisi, A. I., Olatunji, L. M., \& Ekpenyong, B. I. (2013). Monetary policy and its implications for Balance of payments stability in Nigeria: 1980-2010. International Journal of Economics and Finance, 5(3), 196-204.

Imoughele, L. E., \& Ismaila, M. (2015). Monetary policy and balance of payments stability in Nigeria. International Journal of Academic Research in Public Policy and Governance, 2(1), 1-14.

Kumar, V., Acharya, S., \& Ho, L. T. H. (2020). Does monetary policy influence the profitability of Banks in New Zealand?. International Journal of Financial Studies, 8(35), 1-17. https://doi.org/10.3390/ijfs8020035

Lawal, A. I., Somoye, R. O., Babajide, A. A., \& Nwanji, T. I. (2018). The effect of fiscal and Monetary policies interaction on stock market performance: Evidence from Nigeria. Future Business Journal, 4(2018), 16-33. https://doi.org/10.1016/j.fbj.2017.11.004

Miftahu, I. (2019). Monetary policy and economic growth in developing countries: evaluating the policy nexus in Nigeria. International Journal of Business and Economics Research, 8(5), 303-313. https://doi.org/10.11648/j.ijber.20190805.17

Nguyen, T. M. L. (2019). Output effects of monetary policy in emerging and developing countries: evidence from a Meta-Analysis. Emerging Markets Finance and Trade, 1-18. https://doi.org/10.1080/1540496x.2019.1601081

Nguyen, T. M. L., Papyrakis, E., \& Bergeijk, P. A. G. V. (2019). Assessing the price and output effects of monetary policy in Vietnam: evidence from a V.A.R. analysis. Applied Economics, 51(44), 4800-4819. https://doi.org/10.1080/00036846.2019.1602708

Okonkwo, O. N., Egbulonu, K. G., \& Emerenini, F. M. (2015). Monetary policy and the Manufacturing sector in Nigeria. S.S.R.G. International Journal of Economics and Management Studies, 2(1), 11-19. 
Omodero, C. O. (2020). Capital market response to monetary policy shocks: Evidence from Nigeria. Academy of Accounting and Financial Studies Journal, 24(3), 1-11.

Omotor, D. G. (2007). Monetary policy and economic growth: theoretical and conceptual issues. CBN Economic and Financial Review, 45(4), 39-67.

Osakwe, A. C., Ibenta, S. N. O., \& Ezeabasili, V. N. (2019). Monetary policy and the performance of the manufacturing sector in Nigeria (1986-2017). International Journal of Academic Research in Business \& Social Science, 9(2), 399-413. https://doi.org/10.6007/IJARBSS/v9-i2/5553

Rami, O., \& Bassam, A. (2017). Effectiveness of monetary policy instruments on economic growth in Jordan using vector error correction model. International Journal of Economics and Finance, 9(11), 194-206.

Rezabek, P., \& Doucek, P. (2018). Monetary and Fiscal Policy Interactions in the Czech Republic. Systems, 6(25), 1-13. https://doi.org/10.3390/systems6020025

Srithilat, K., \& Sun, G. (2017). The impact of monetary policy on economic development: Evidence from Lao P.D.R. Global Journal of Human Social Science: E Economics, 17(2), 8-16.

Twinoburyo, E. N., \& Odhiambo, N. M. (2018). Monetary policy and economic growth: A review of International Literature. Journal of Central Banking Theory and Practice, 2018(2), 123-137. https://doi.org/10.2478/jcbtp-2018-0015

Ufoeze, L. O., Odimgbe, S. O., Ezeabalisi, V. N., \& Alajekwu, U. B. (2018). Effect of monetary Policy on economic growth in Nigeria: An empirical investigation. Annals of Spiru Haret University Economic Series, (1), 123-140.

Williams, J. (2017). Monetary policy's role in fostering sustainable economic growth. F.R.B.S.F. Economic Letter, (22).

\section{Copyrights}

Copyright for this article is retained by the author(s), with first publication rights granted to the journal.

This is an open-access article distributed under the terms and conditions of the Creative Commons Attribution license (http://creativecommons.org/licenses/by/4.0/). 